\title{
FURTHER RADIOCARBON DATES FOR THE UPPER PALEOLITHIC OF EL MIRÓN CAVE (RAMALES DE LA VICTORIA, CANTABRIA, SPAIN)
}

\section{Lawrence Guy Straus}

Department of Anthropology, MSC01 1040, University of New Mexico, Albuquerque, New Mexico 87131-0001, USA.

Corresponding author. Email: 1straus@unm.edu.

\section{Manuel R González Morales}

Instituto Internacional de Investigaciones Prehistóricas, Universidad de Cantabria, Avda. de los Castros, 39005 Santander, Spain. Email: moralesm@unican.es.

\begin{abstract}
This article expands the date list from the Stone Age cave site of El Mirón in the Cantabrian Cordillera of northern Spain to a total of 62 radiocarbon determinations, one of the longest series from a single prehistoric site in Iberia. All the assays (accelerator mass spectrometry [AMS] and conventional, run on charcoal and bone collagen) were done by a single laboratory (Geochron, GX). The 11 new dates confirm 1) the late spread of Neolithic economy and technology into the Atlantic environment of Cantabrian Spain by about $4500 \mathrm{cal} \mathrm{BC}$; 2) the horizontally extensive, but not intensive, use of the whole cave vestibule by Upper Magdalenian foragers about 12,000-14,000 cal BC; 3) extensive and very intensive, repeated occupations of the cave during the Middle and Lower Cantabrian Magdalenian about 14,200-17,000 cal BC; and 4) a long, gradual technological transition from the Solutrean to the Archaic Magdalenian between about 20,000-17,000 cal BC. El Mirón joins a list of culturally very rich, frequently occupied, Lower Magdalenian residential hub sites-most of the rest of which (including Altamira) are located in the coastal lowlands of Cantabria — which have yielded distinctive red deer scapulae that are decorated with striated engraved images of game animals (mainly red deer hinds), now most precisely dated at El Mirón between $16,200-17,200$ cal BC.
\end{abstract}

\section{INTRODUCTION}

In an earlier article (Straus and González Morales 2003), we presented 51 radiocarbon dates from human occupations in El Mirón Cave that spanned the period between the late Middle Paleolithic and the late Middle Ages (41,000 BP-AD 1400). Already one of the largest series of dates from any single (mostly) prehistoric site in Spain or Europe after the first 7 excavation campaigns that began in 1996, the El Mirón date list has expanded considerably with the production of 11 more determinations (total $n=62$ ) during the course of the subsequent 5 field seasons in the cave (Figure 1). The

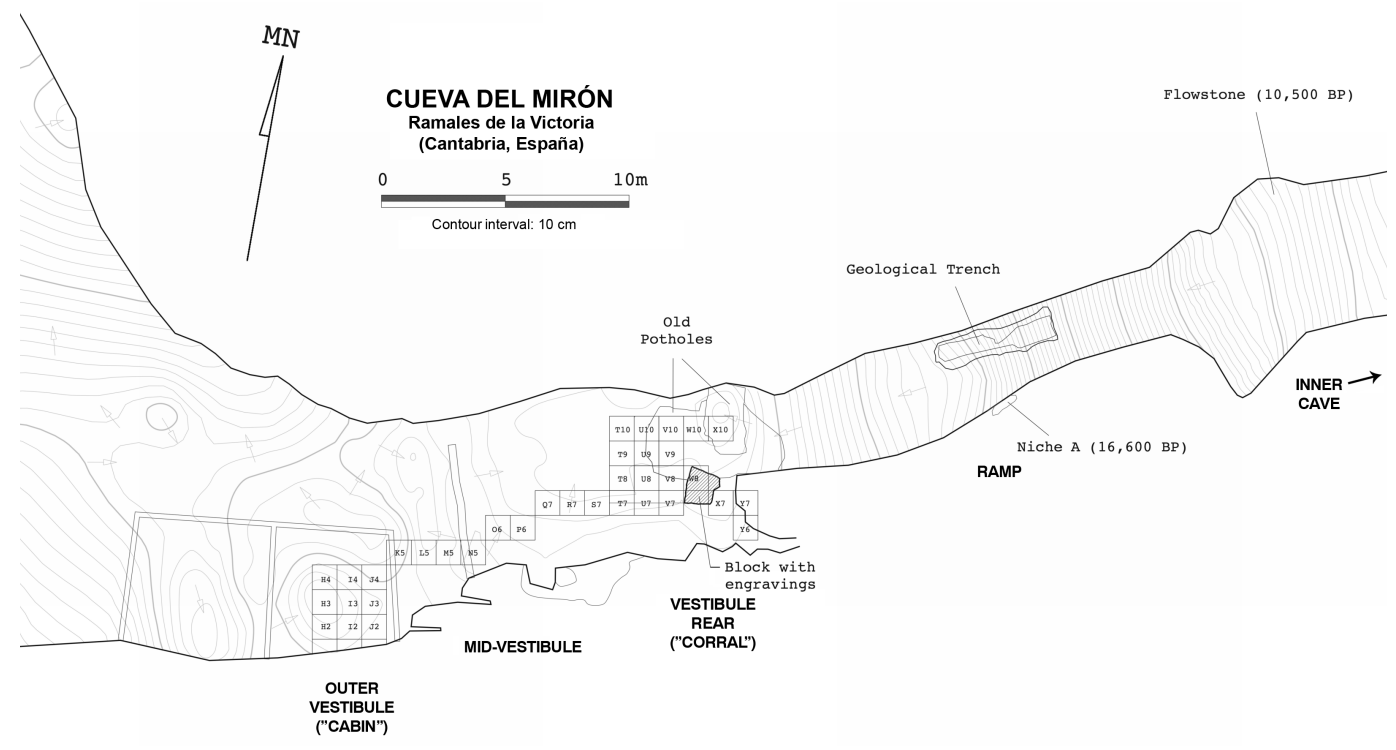

Figure 1 Plan of El Mirón Cave vestibule, showing excavation areas. Topography by E Torres. 
purpose of this brief article is to present the additional dates, all of which-like the earlier oneswere run by Geochron Laboratories under the supervision of Alexander Cherkinsky. The new dates mainly concern the early Magdalenian and transition between the Solutrean and Magdalenian cultures during the early-mid Würm Tardiglacial (late oxygen isotope stage 2). While the sequences of dates from the block excavation area in the front of the cave vestibule (Figure 2) and in the mid-vestibule connecting trench (Figure 3) continue to be stratigraphically coherent, inconsistencies still complicate the dating of the cultural deposits in the block excavation area at the vestibule rear (Figure 4). These problems are discussed in the conclusion of the article. Stratigraphic correlations among the 3 contiguous vestibule excavation areas, as well as to discrete units in the inner cave, are given in Table 1.

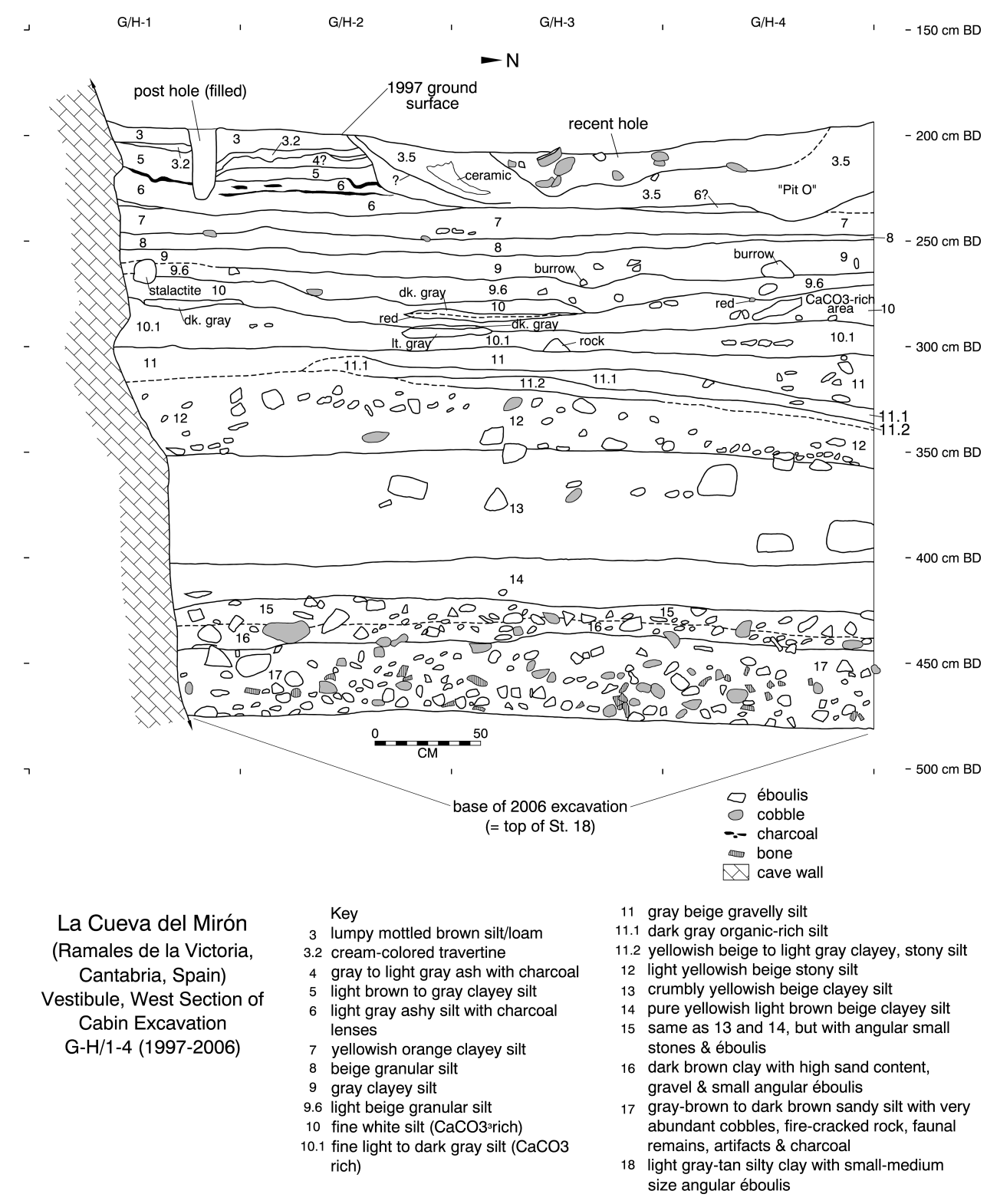

Figure 2 West section of the "Cabin" (vestibule front) excavation area 


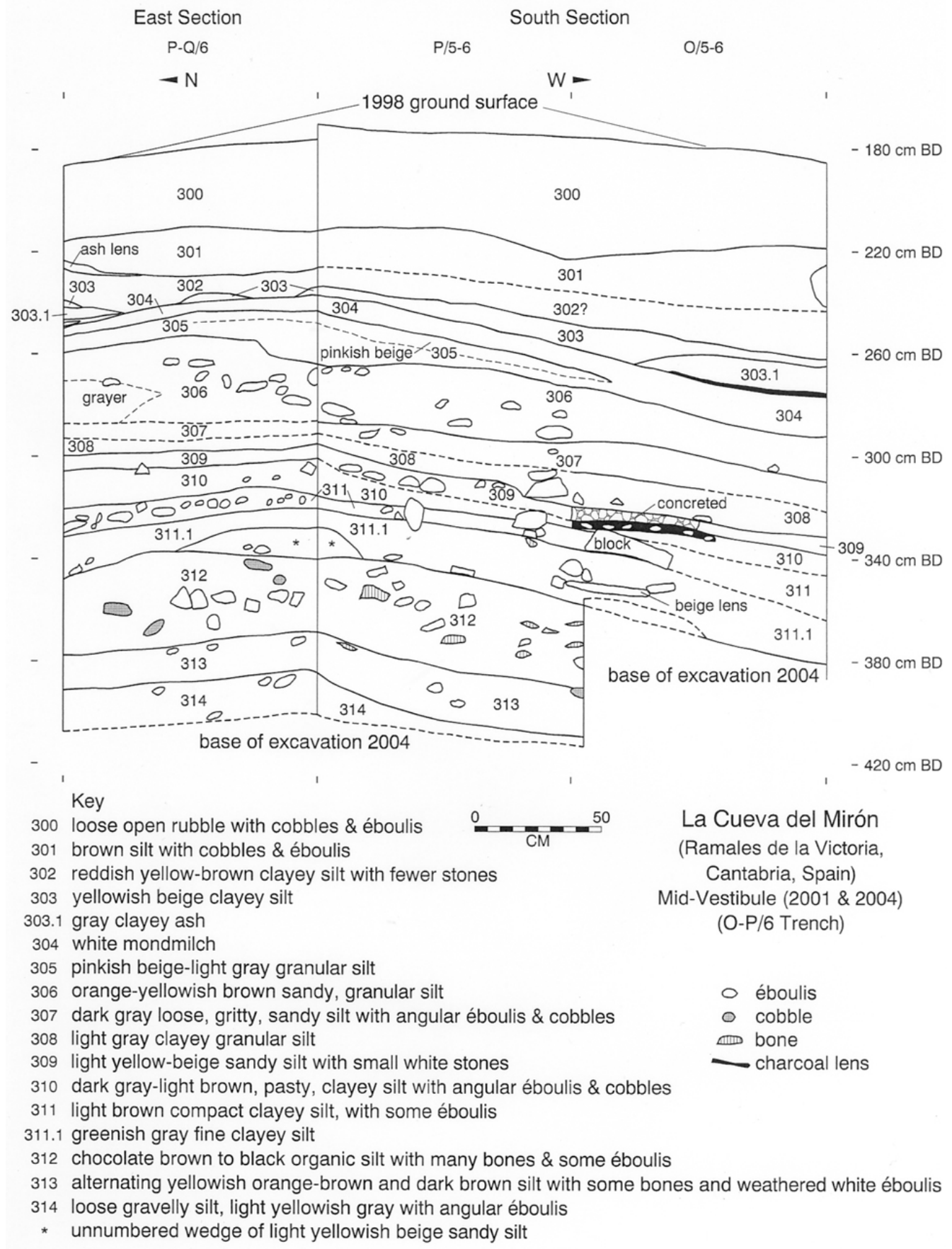

Figure 3 South and East sections of the O-P/6 sondage within the mid-vestibule trench 


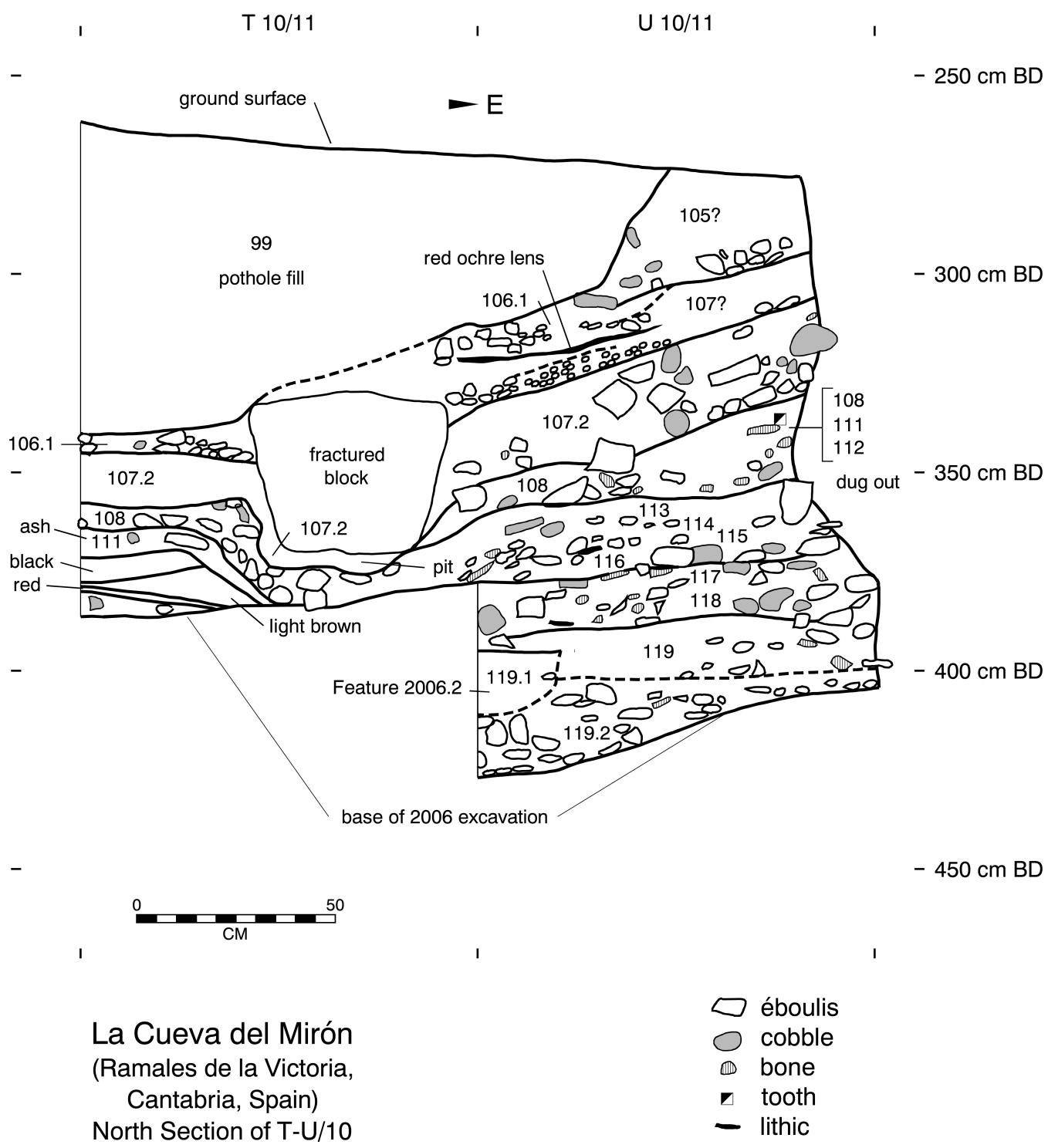

Figure 4 North section of the "Corral" (vestibule rear) excavation area

\section{THE NEW DATES}

Table 2 presents the new dates by zone within the cave and in reverse stratigraphic order.

GX-30910 was done on a single grain of Triticum aestivum/durum wheat from Level 303.3, the lowest level in the mid-vestibule trench that also has plainware ceramics and domesticated animals (Altuna et al. 2002; Peña-Chocarro et al. 2005). The date of 5500 BP (about 4400 cal BC) is fully concordant with the earliest Neolithic dates from both the mid-vestibule (levels 303.3-303) and the contiguous outer vestibule excavation area (Level 10). The 6 dates from these layers suggest that the early Neolithic stratum was deposited rapidly. The dates are the earliest for a fully developed Neolithic in trans-Cordilleran Vasco-Cantabria, and suggest a rapid final "advance" of food produc- 
Table 1 Correlations among Stone Age levels in the various excavation areas of El Mirón Cave.

\begin{tabular}{llllll}
\hline $\begin{array}{l}\text { Outer } \\
\text { vestibule }\end{array}$ & Mid-vestibule & $\begin{array}{l}\text { Vestibule } \\
\text { rear }\end{array}$ & Ramp & $\begin{array}{l}\text { Inner } \\
\text { cave }\end{array}$ & \begin{tabular}{l} 
Cultural phase \\
\hline $3-2$
\end{tabular} \\
& Surface & & $\begin{array}{l}\text { IV } \\
\text { VII }\end{array}$ & $\begin{array}{l}\text { Medieval } \\
\text { Bronze Age } \\
\text { Chalcolithic }\end{array}$ \\
$7-4$ & & & & Neolithic \\
$10-8$ & $303.3-302$ base & & & & Mesolithic \\
10.1 & 304 & $101-102$ & & & Azilian \\
$11.2-11$ & $306-305$ & 102.1 & Breccia & & Late Magdalenian \\
12 & $308-307$ & $107-103$ & & & Early Magdalenian \\
$17-13$ & $312-309$ & $119.2-108$ & Niche A & VIII & Solutrean \\
& $313(?)$ & $126-120$ & & & Early Upper Paleolithic \\
& & $128-127$ & & & Final Middle Paleolithic \\
\hline
\end{tabular}

Table 2 El Mirón Cave ${ }^{14} \mathrm{C}$ dates (2003-2006).

\begin{tabular}{|c|c|c|c|c|c|c|c|c|c|c|}
\hline Square & Zone $^{a}$ & Level & Spit & Period $^{b}$ & $\begin{array}{l}\text { Date } \\
\text { (BP) }\end{array}$ & $1 \sigma$ & Material $^{\mathrm{c}}$ & Lab nr & Method $^{\mathrm{d}}$ & $\begin{array}{l}\text { Calibrated date } \\
\text { (BC) }\end{array}$ \\
\hline $\mathrm{H}-\mathrm{J}$ rows & $\mathrm{OV}$ & 41 & sev. & MM & 14,600 & 190 & $\mathrm{Bc}$ & GX-32383 & Conv & $15,870-15,210$ \\
\hline $\mathrm{H} 3$ & $\mathrm{OV}$ & 17 & 79 & $\mathrm{LM}$ & 15,370 & 80 & $\mathrm{Ch}$ & GX-32654 & AMS & $16,720-16,140$ \\
\hline M5 & MV & 303.3 & 10 & $\mathrm{Neo}$ & 5550 & 40 & Grain & GX-30910 & AMS & $4450-4340$ \\
\hline P6 & MV & 312 & 25 & LM & 15,850 & 170 & $\mathrm{Bc}$ & GX-31932 & Conv & $17,330-16,630$ \\
\hline P6 & MV & 313 & 29 & Sol? & 17,400 & 270 & $\mathrm{Bc}$ & GX-31194 & Conv & $19,200-18,310$ \\
\hline $\mathrm{U}-\mathrm{V}$ rows & VR & 106 & sev. & UM & 12,460 & 180 & $\mathrm{Bc}$ & GX-32382 & Cxent & $13,480-12,210$ \\
\hline $\mathrm{U} 7$ & VR & 108 & 10 & MM & 13,710 & 70 & $\mathrm{Bc}$ & GX-32381 & AMS & $14,750-14,270$ \\
\hline U10 & VR & 118 & 38 & $\mathrm{LM}$ & 15,460 & 190 & $\mathrm{Ch}$ & GX-31933 & Cxent & $16,880-16,170$ \\
\hline U9 & VR & 119.2 & 52 & LM & 16,320 & 160 & $\mathrm{Bc}$ & GX-32656 & Conv & $17,870-18,160$ \\
\hline V9 & VR & 121 & 3 & Sol & 18,390 & 300 & $\mathrm{Bc}$ & GX-32655 & Cxent & $19,420-20,380$ \\
\hline Mid-Slope & & Niche & & LM & 16,600 & 90 & $\mathrm{Bc}$ & GX-30398 & AMS & $18,160-17,510$ \\
\hline
\end{tabular}

aOV = outer vestibule ("Cabin"); VR = vestibule rear ("Corral”); MV = mid-vestibule ("Trench").

${ }^{\mathrm{b}} \mathrm{Neo}=$ Neolithic; $\mathrm{UM}=$ Upper Magdalenian; $\mathrm{MM}=$ Middle Magdalenian; $\mathrm{LM}=$ Lower Magdalenian; Sol = Solutrean .

(The distinction between the Middle and Lower Magdalenian is tentative.)

${ }^{\mathrm{c}} \mathrm{Ch}=$ charcoal; $\mathrm{Bc}=$ bone collagen.

${ }^{\mathrm{d}} \mathrm{AMS}=$ accelerator C Conv $=$ conventional Cxent $=$ extended count.

${ }^{\mathrm{e}}$ Stuiver et al. (1998); CALIB 4.1.2 (range at $1 \sigma$; calibrated dates rounded to nearest $10 \mathrm{yr}$ ).

tion economies and associated technologies into north-central Spain, from either SW France or the upper Ebro Valley in Mediterranean Spain (see Alday Ruiz 2005). This is important in the overall study of the delayed spread of the Neolithic and its relationship to local Mesolithic lifeways along the Atlantic façade of Europe (see Arias 1999).

GX-32382, done on carbonized bone collagen from several diaphysis fragments from Level 106 in the vestibule rear, confirms the continuous existence of an Upper Magdalenian occupation of the El Mirón vestibule (from the rear, through the middle, and into the outer area) with 3 dates between $\sim 13,000$ to $\sim 12,400$ BP (around 13,500-13,000 cal BC). This was not a particularly rich series of occupations in terms of densities of artifacts (there is only 1 unilaterally barbed harpoon from Level 12 in the outer vestibule), hearths, or faunal remains, at least in comparison to the underlying Middle-Lower-Initial Magdalenian occupations. Although El Mirón Cave was obviously used by humans during the Last Glacial interstadial, the Upper Magdalenian (and Azilian) occupations of 
the upper-middle Asón Valley were apparently concentrated in El Horno and El Valle caves, and artistic activity seems to have focused on Cullalvera Cave, all located at the valley floor rather than high above it in El Mirón (Straus et al. 2002a,b, 2006; González Morales and Straus 2005; Straus and González Morales 2005).

The Middle Magdalenian (defined by the presence of typical artifacts such as cut-out bone effigies of animal heads [contours découpés] and dated to about 15,000-13,000 BP in several coastal Cantabrian and Asturian sites) is poorly characterized at El Mirón. However, occupations pertaining to late Dryas I clearly did occur in the cave vestibule and inner cave. The latest dates (GX-32383 for Level 14 in the outer vestibule and GX-32381 for Level 108) are stratigraphically coherent. These levels probably correspond to undated levels 309-311.1 in the mid-vestibule trench and they definitely coincide with inner cave Level VIII, which is dated to 14,620 BP. Level 108 poses certain problems because it now has $4{ }^{14} \mathrm{C}$ determinations: 3 on bone and 1 (the oldest) on charcoal from a dug-out hearth. They range between 13,660 and 14,850 BP. It is possible that some of the bone collagen samples were "rejuvenated" by the percolation of organic matter from overlying levels, while the basal hearth charcoal could have been contaminated by older particles from the underlying level.

The classic Cantabrian Lower Magdalenian (most famously present at such sites as Altamira, El Juyo, and El Castillo in or near the coastal zone of central Cantabria) is abundantly represented throughout the El Mirón vestibule. Like the coastal sites, El Mirón contains masses of lithic artifacts (knapping debris and finished tools and weapon elements), osseous artifacts (notably projectile points and needles), bones and teeth of ibex and red deer, salmon vertebrae, charcoal, fire-cracked rocks, pecked cobble anvils, and actual hearths built in pits or on living surfaces, etc. Also like them, El Mirón has yielded engraved scapulae, notably 1 large red deer stag shoulder blade with the image of a red deer hind (and an incomplete figure of a bovine). Such objects are absolutely distinctive of the Lower Magdalenian of Cantabria (with 1 outlier site in eastern Asturias), and the El Mirón finds are among the very best-dated and contextualized thereof (González Morales et al. 2007). In particular, Level 17 in the outer vestibule, which yielded the complete engraved scapula discarded in the midst of this very dense midden deposit, is now dated by $4{ }^{14} \mathrm{C}$ assays, the newest of which is GX32654. This date is the youngest of the 4 despite being the stratigraphically lowest within the level, although all 4 dates lie within $1 \sigma$ of one another. These results suggest that the $30-45$-cm-thick Level 17 was formed very rapidly by a series of intensive human occupations during mid-Dryas I times. It (together with levels 15-16) is continuous with the coarsely defined, 30-35-cm-thick Level 312 that was excavated in a $1-\mathrm{m}^{2}$ test pit within the mid-vestibule trench and whose middle is now dated to $15,850 \pm 170 \mathrm{BP}(\mathrm{GX}-31932)$. This in turn is physically continuous with an ensemble of more finely defined levels (total thickness: $\sim 25-40 \mathrm{~cm}$ ) in the vestibule rear (levels 109-116), globally dated between about 15,200-16,460 BP. (Less spectacular fragments of engraved scapulae have been found in both Level 17 and Level 116.) In 2007, lower Level 17 yielded a possible spearthrower. If functional doubts raised by its thinness can be removed, this would be only the second spearthrower to be found in Spain and one of the better-dated and older ones anywhere in Europe, save for a Solutrean one at Combe-Saunière (Cattelain 2005).

These extraordinarily rich levels $(15-17,312,108-116)$ are clearly local manifestations of the same continuous, extensive palimpsest cultural deposit throughout the Mirón vestibule and that had even once existed atop the erosional slope (as judged from the remnant in-filling of a niche in the cave wall dated to $16,600 \mathrm{BP}$ ). They are all dark "chocolate" brown to black in color, attesting to their great organic content. They represent major, repeated, functionally complex, temporally extended occupations of the cave - probably by relatively large human groups-during the early part of the late Last Glacial. 
Few of the other striation-engraved scapulae from the region are ${ }^{14} \mathrm{C}$ dated, although recently such an object from the early 20th century excavation in Altamira Cave was directly dated by AMS, yielding a surprisingly young result of $14,480 \pm 250 \mathrm{BP}$ (GifA-90057). The 50-75-cm-thick stratum in question has been dated by 4 other assays, ranging between 13,900-15,910 BP (Valladas et al. 1992; Bernaldo de Quirós and Cabrera Valdés 1994; Freeman and González Echegaray 2001). The level bearing such engraved scapulae in El Juyo Cave is between levels dated to 14,400 \pm 180 and $15,300 \pm 700 \mathrm{BP}$ (Freeman and González Echegaray 1995). The several engraved scapulae from El Castillo Cave were found in the early 20th century in a 1.2- to 2-m-thick early Magdalenian stratum, from which a decorated bone point has been AMS dated to 16,850 $\pm 220 \mathrm{BP}$ (presumably from the basal part of the layer) (Barandiarán 1988). The highly distinctive engraved scapulae, best dated in El Mirón, clearly mark a specific cultural phase in the center of Cantabrian region, with an extension now demonstrated as having stretched at most $120 \mathrm{~km}$ east-west between the valleys of the Asón and the Sella (but mainly the $55 \mathrm{~km}$ between the Saja-Besaya and the Asón) and from the coast to the Cordillera $(\sim 25 \mathrm{~km})$. Most of the cultural strata in question-notably those of El Castillo, El Juyo, and Altamira, like those of El Mirón — are obviously major palimpsest deposits formed by significant, repeated residential occupations of cave, which can be hypothesized to have been "hub" or "base" camps for Lower Magdalenian hunter-gatherer-fishers. The area demarcated by the distribution of the striation-engraved scapulae could well have corresponded to the territory of a distinct regional band, a phenomenon which, for the first time in the long record of human cultural evolution, one can begin credibly to discern in the late Upper Paleolithic (e.g. Conkey 1980; Straus 1986; Menéndez 2003; Corchón 2005; Schwendler 2005).

In contrast to the absolute stratigraphic coherence of the ${ }^{14} \mathrm{C}$ dates from the outer and mid-vestibule excavations, there continue to be marked (and as yet unexplained) inconsistencies among the many Magdalenian-age dates from the vestibule rear. This is the case with the assay from basal Magdalenian level 119.2 (16,320 $\pm 160 \mathrm{BP}$ [GX-32656]), which is younger than a date from (apparently) overlying level 119 in a diagonally adjacent square. In this area, there are several reversals in date order, even within individual squares, where it can be assumed that the basic stratigraphy is sound. In the vestibule rear (unlike the vestibule front, where the levels are flat), the Magdalenian levels have a double slope: down toward the cave mouth (west) and toward the north. There are clearly lateral variations in sedimentology between north and south, even within this $10-\mathrm{m}^{2}$ excavation area, probably related to each square's position relative to the narrow gallery leading up to the inner cave along the north edge of the cave axis. Since there are no culturally sterile layers and many thin, but highly localized lenses and patches characterized by sediment color and texture (some clearly formed by human fire activity and ochre pigment use, but others possibly deposited by gentle, surface flow wash episodes from the inner cave, such as continue to occur every winter), it is exceedingly hard to "follow" individual occupational surfaces or even levels (none more than a few $\mathrm{cm}$ thick) across the $10 \mathrm{~m}^{2}$ of the vestibule rear excavation area. This fact, coupled with the double slope, could conceivably cause false archaeological attributions of differently aged sediments to the same thin "levels," but some of the dates (even excluding one with an inexplicably large standard deviation of $840 \mathrm{yr}$ ) deviate from others within the same or an under-/over-lying level by as much as about $1000 \mathrm{yr}$, making it therefore difficult to know whether to accept a "long" or "short" chronology for several of the levels in question (i.e. levels 108-119.2).

Two (not mutually exclusive) hypotheses are that 1 ) intense, repeated prehistoric human activity (e.g. scuffing, trampling, leveling, hearth-pit digging, and cleaning) may have moved bones and pieces of charcoal both horizontally and vertically ( 2 of the "old" dates from 2 different levels that have multiple dates are from visible hearth fills, which could include materials dug up from under- 


\section{L G Straus \& M R González Morales}

lying levels in antiquity); and 2) decomposition of abundant organic matter (e.g. carcass parts, excrement, wood) in this humid, generally shaded rear area of the vestibule may have caused the percolation of humic acid contaminants that unevenly affected the apparent age of the bones, although there are also stratigraphically inconsistent charcoal dates). Differences in decomposition processes between the vestibule front and middle versus the rear are hinted at by the blackened coloration of most of the bones from the latter area, in part explainable by the organic production of manganese oxide in the sediments there, but not in the more sunlit, but thermally variable outer areas of the cave (Marín Arroyo et al. 2007). Whatever the explanation(s) for the stratigraphic reversals among specific dates in the vestibule rear may be, it is apparent that Level 102.1 is about 12,000 ${ }^{14} \mathrm{C}$ yr old (terminal Magdalenian/initial Azilian), Level 108 about 14,000-15,000, levels 110-111 about 16,000, levels 114-119.2 about 16,500-17,000, constituting one of the most complete sequences for the early Magdalenian in Spain, with the possibility for distinguishing various subphases (i.e. Initial, Classic Lower, and Middle).

The last "new" ${ }^{14} \mathrm{C}$ date from El Mirón adds to our chronological evidence on the controversial question of the transition between the Solutrean and Magdalenian technological traditions, both at this site specifically and throughout the Cantabrian region in general. This is a determination of $18,390 \pm 300 \mathrm{BP}(\mathrm{GX}-32655)$ from Level 121 that is stratigraphically coherent with dates from underlying levels 125 and 126 of about 19,000 BP. Level 121 has not (yet) yielded characteristic Solutrean leaf-shaped or shouldered points, perhaps simply because of the small area in which it has been excavated $\left(4 \mathrm{~m}^{2}\right)$. While the Solutrean attribution of point-rich levels 122-127 is clear and there is 1 point fragment in Level 120, the cultural assignment of levels 119.2-119 (like that of midvestibule Level 313, with a "Solutrean-age" ${ }^{14} \mathrm{C}$ date of $17,400 \pm 270 \mathrm{BP}$, but no points [albeit from a $1-\mathrm{m}^{2}$ test pit]) is problematic, because of the $16,960 \pm 80 \mathrm{BP}$ date and a pair of apparent Solutrean point fragments from Level 119. How much of this overlap is explainable by a cultural process of technological transition and how much might be the result of mechanical mixing, erosion, and/or Magdalenian "collecting" is as hard to determine here as it was in La Riera Cave in Asturias (see Straus 1983; Straus and Clark 1986; contra Rasilla and Llana 1994; contra Straus 1995). A process of gradual, in situ development of the local early Magdalenian out of the local Solutrean (e.g. Straus 1975) continues to be a plausible hypothesis, particularly in light of "Solutrean" dates at other regional sites such as Amalda (Guipúzcoa) and El Ruso (Cantabria) that overlap with earliest "Magdalenian" dates at other sites (see Soto-Barreiro 2003; Rasilla and Straus 2007).

The El Mirón Initial Magdalenian levels (117-119) are characterized by high frequencies of debris and "macrolithic" tools of archaic appearance, made on locally available mudstone, quartzite, and limestone. These contrast with the more "microlithic" assemblages of some of the overlying Lower Magdalenian levels that are made on excellent-quality flints, some of which are probably from Cretaceous outcrops as far as 40-50 km from the site (Rissetto 2005). Assemblages of Solutrean and early Magdalenian ${ }^{14} \mathrm{C}$ age, but with many "Mousterian-looking" sidescrapers, denticulates, notches, and even choppers on non-flint raw materials are well-known in the Cantabrian region

\section{CONCLUSIONS}

In El Mirón Cave, with a long, well-stratified depositional infilling that spans terminal oxygen isotope stage 3 , all of stage 2 , and most of stage 1 (Straus et al. 2001), extensive utilization of ${ }^{14} \mathrm{C}$ dating has achieved important results. These both confirm and provide further precision for the ages of well-recognized regional archaeological hallmarks (e.g. the first appearance of domesticated cereals and animals and of ceramics; the invention of the barbed antler harpoon; the distinctive regional "horizon style" of striation-engraved scapulae; the initial appearance and then gradual substitution of lithic Solutrean projectile points). They also allow us to chronologically place and correlate levels 
in different sectors of the site that (due to the vicissitudes of prehistoric activity area location and of archaeological sampling) lack temporally diagnostic artifacts. Most spectacularly, the ${ }^{14} \mathrm{C}$ dates permit us to conclude that during the Initial-Lower Magdalenian humans were using not only the whole, large, sunlit vestibule, but also the ramp area and the dark inner cave. Because of its long cultural sequence, extensive, controlled excavation and long list of ${ }^{14} \mathrm{C}$ dates, El Mirón has already become one of the chronological "anchors" of the Upper and Post-Paleolithic record in Cantabrian Spain, joining La Riera Cave, where, in the mid-1970s, Straus and Clark (1986) had deliberately placed a heavy emphasis on ${ }^{14} \mathrm{C}$ dating as an independent measure of ages for a relatively long series of occupation horizons until then mainly "dated" only by artifacts.

Unfortunately, in what seems to be an inevitable "trade-off" whenever an archaeological site is dated by large numbers of ${ }^{14} \mathrm{C}$ assays, like La Riera, the El Mirón sequence has a number of inconsistencies, despite the careful selection of samples and use of a single laboratory to try to eliminate at least some potential sources of "error." Interestingly, the incoherencies are essentially confined to the vestibule rear. Whether they are due to prehistoric disturbances, slope erosion, problems of archaeological level micro-correlation, and/or the uneven downward percolation of organic material (e.g. from slowly decomposing carcass parts), cannot be determined at this time. But solving the problem is now one of the research foci of the El Mirón Project. Luckily, the overall trends among the dates even in the vestibule rear are clear and reasonable, even if, for certain levels, one has a choice between "long" and "short" chronologies.

\section{ACKNOWLEDGMENTS}

El Mirón Cave excavations and analyses since 1996 have been funded by the National Science Foundation, Fundación M Botín, National Geographic Society, Gobierno de Cantabria, LSB Leakey Foundation, Ministerio de Educación y Ciencia, and University of New Mexico, with material support from the Universidad de Cantabria and Villa de Ramales de la Victoria. Alex Cherkinsky, formerly of Geochron Labs, carried out all the ${ }^{14} \mathrm{C}$ dating from El Mirón. Straus' stratigraphic section drawings were redrafted by Ron Stauber (UNM-OCA).

\section{REFERENCES}

Alday Ruiz A. 2005. The transition between the last hunter-gatherers and the first farmers in southwestern Europe: the Basque perspective. Journal of Anthropological Research 61(4):469-94

Altuna J, Cuenca G, Elorza M, García J, Lobo J, Mariezkurrena K, Pérez M, Sanchiz B, González Morales M, Straus LG. 2002. Post-Pleistocene faunas from the archaeological site of El Mirón Cave: a preliminary summary. In: Baquedano E, Rubio S, editors. Miscelánea en Homenaje a Emilio Aguirre (Zona Arqueológica 4). Volume II. Alcalá: Museo Arqueológico Regional. p 40-9.

Arias P. 1999. The origins of the Neolithic along the Atlantic coast of continental Europe: a survey. Journal of World Prehistory 13(4):403-64.

Barandiarán I. 1988. Datation C14 de l'art mobilier magdalénien cantabrique. Bulletin de la Société Préhistorique Ariège-Pyrénées 43:63-84.

Bernaldo de Quirós F, Cabrera Valdés V. 1994. Cronología del arte paleolítico. Complutum 5:265-76. In Spanish.
Cattelain P. 2005. Propulseurs magdaléniens: marqueurs culturels régionaux? In: Dujardin V, editor. Industrie Osseuse et Parures du Solutréen au Magdalénien en Europe. Paris: Mémoires de la Société Préhistorique Française 39. p 301-17. In French.

Conkey MW. 1980. The identification of prehistoric hunter-gatherer aggregation sites: the case of Altamira. Current Anthropology 21(5):609-30.

Corchón M. 2005. Europa 16500-14000 a.C.: un lenguaje común. In: Arias P, Ontañón R, editors. La Materia del Lenguaje Prehistórico. Santander: Gobierno de Cantabria. p 105-26. In Spanish.

Freeman L, González Echegaray J. 1995. The Magdalenian site of El Juyo (Cantabria, Spain). Artistic documents in context. Bolletino del Centro Camuno di Studi Preistorici 28:25-42

González Morales M, Straus LG. 2005. The Magdalenian sequence of El Mirón Cave. In: Dujardin V, editor. Industrie Osseuse et Parures du Solutréen au Magdalénien en Europe. Paris: Mémoires de la Société Préhistorique Française 39. p 209-19. 
González Morales M, Straus LG, Marín AB. 2007. Los omóplatos decorados magdalenienses de la Cueva del Mirón y su relación con las cuevas del Castillo, Altamira y El Juyo. In: Maillo JM, Baquedano E, editors. Homenaje a Victoria Cabrera Valdes (Zona Arqueológica 7). Alcalá: Museo Arqueológico Regional. p 3-12. In Spanish.

Marín Arroyo AB, Landete Ruiz M, Vidal Bernabeu G, Seva Román R, González Morales MR, Straus LG. 2007. The archaeological implications of human-derived manganese coatings: a study of blackened bones in El Mirón Cave, Cantabrian Spain. Journal of Archaeological Science doi: 10.1016/j.jas.2007.06.007.

Menéndez M. 2003. Arte prehistórico y territorialidad en la cuenca del Río Sella. In: Balbín Behrmann R, Bueno Ramírez P, editors. El Arte Prehistórico Desde los Inicios del Siglo XXI: Primer Symposium Internacional de Arte Prehistórico de Ribadesella. Ribadesella: Asociación Cultural Amigos de Ribadesella. p 185-99. In Spanish.

Peña-Chocarro L, Zapata L, Iriarte MJ, González Morales M, Straus LG. 2005. The oldest agriculture in northern Atlantic Spain: new evidence from El Mirón Cave (Ramales de la Victoria, Cantabria). Journal of Archaeological Science 32:(4)579-87.

Rasilla M, Llana C. 1994. La cronología radiométrica del Solutrense en la Península Ibérica y su correlación crono-climática. Férvedes 1:57-67. In Spanish.

Rasilla M, Straus LG. 2007. El poblamiento en la región cantábrica en torno al Ultimo Máximo Glacial: Gravetiense y Solutrense. In: Fano M, editor. Las Sociedades del Paleolítico en la Región Cantábrica. Bilbao: Kobie (Serie Anejo 8). p 209-42. In Spanish.

Rissetto J. 2005. Using lithic procurement strategies to define Magdalenian hunter-gatherer patterns in the Asón Valley of eastern Cantabria, Spain. In: Bicho N, editor. O Paleolítico. Actas do IV Congresso de Arqueologia Peninsular. Faro (Promontoria Monografica 2). p 481-92.

Schwendler R. 2005. Magdalenian perforated bone disks in geographic and social contexts. In: Dujardin V, editor. Industrie Osseuse et Parures du Solutréen au Magdalénien en Europe. Paris: Mémoires de la Société Préhistorique Française 39. p 73-84.

Soto-Barreiro MJ. 2003. Cronología Radiométrica, Ecología y Clima del Paleolítico Cantábrico. Madrid: Monografías del Museo Nacional y Centro de Investigación de Altamira 19. In Spanish.
Straus LG. 1975. ¿Solutrense o Magdaleniense inferior cantábrico? Significado de las 'diferencias.' Boletín del Instituto de Estudios Asturianos 86:781-90. In Spanish.

Straus LG. 1983. El Solutrense Vasco-Cantábrico: Una Nueva Perspectiva. Madrid: Monografías del Centro de Investigación y Museo de Altamira 10. In Spanish.

Straus LG. 1986. Late Würm adaptive systems in Cantabrian Spain: the case of eastern Asturias. Journal of Anthropological Archaeology 5(4):330-68.

Straus LG. 1995. Reflexiones sobre el estado de la investigación del Solutrense vasco-cantábrico. Férvedes 2 : 23-33. In Spanish.

Straus LG, Clark GA. 1986. La Riera Cave. Tempe: Arizona State University. Anthropological Research Papers 36.

Straus LG, González Morales M. 2003. El Mirón Cave and the ${ }^{14} \mathrm{C}$ chronology of Cantabrian Spain. Radiocarbon 45(1):41-58.

Straus LG, González Morales M. 2005. El Magdaleniense de la Cueva del Mirón: observaciones preliminares. In: Bicho N, editor. O Paleolítico. Actas do IV Congresso de Arqueología Peninsular (Promontoria Monográfica 02). p 49-62.

Straus LG, González Morales M, Farrand WR, Hubbard WJ. 2001. Sedimentological and stratigraphic observations in El Mirón, a late Quaternary cave site in the Cantabrian Cordillera, northern Spain. Geoarchaeology 16(5):603-30.

Straus LG, González Morales MR, Fano Martínez MA, García-Gelabert MP. 2002a. Last Glacial human settlement in eastern Cantabria. Journal of Archaeological Science 29(12):1403-14.

Straus LG, González Morales M, García-Gelabert M, Fano M. 2002b. The Late Quaternary human uses of a natural territory. Journal of Iberian Archaeology 4: 21-61.

Straus LG, González Morales M, Fano M. 2006. The Upper Paleolithic record in the Asón River Basin. In: Noiret P, editor. Le Paléolithique Supérieur Européen. Bilan Quinquennal 2001-2006. Liège: ERAUL 115. p 117-28.

Valladas H, Cachier H, Maurice P, Bernaldo de Quirós F, Clottes J, Cabrera Valdés V, Uzquiano P, Arnold M. 1992. Direct radiocarbon dates for prehistoric paintings at the Altamira, El Castillo and Niaux caves. $\mathrm{Na}$ ture 357(6373):68-70. 